\title{
MODERN ARAB HISTORIANS AND WORLD HISTORY ${ }^{1}$ )
}

The study of modern Arab historiography has hardly begun. Orientalists in Europe and America, as well as Arab historians, until very recently were interested only in medieval Islam and in the classical history of the Arabs. This is why works on Muslim and Arab historiography like those of Wüstenfeld, Margoliouth, and Rosenthal have concerned themselves only with classical Arab historians until the end of the Mamlūk period in the early sixteenth century.

Increasing interest in the modern history of the Arabs, however, is beginning to emphasize the necessity of studying the modern historians and historical literature of the Arab world in the period of Ottoman rule and in the post-war period after 1920 . There is not yet one comprehensive work on the subject, but one Arab author at least, Professor Jamāl al-Din Shayyal, has written a short book on "History and Historians in Egypt in the Nineteenth Century" (Cairo, 1958), 2 The department of Arab Studies at the American University of Beirut devoted its ninth annual conference (18-22 May, 1959) to the study of Arab historiography in the last one hundred years, but the papers presented were almost exclusively centered on modern historical literature relating to various periods of classical Arab history. Not one paper was read on the work of Arab historians on modern Arab history.

General or special works on the history of Arabic literature, like those of C. Brockelmann, Jurji Zaydan and Louis Cheikho, have dealt to some extent with modern Arabic historical literature. It is also good to notice that contemporary writers on modern Arab and Islamic history, such as Gibb and Bowen, S. H. Longrigg, Muhammad Kurd Ali, Asad Rustum, M. Shafiq Ghurbal, and Abbas el-Azzawi, have utilized the historical literature left by the chroniclers, annalists, biographers and other writers since the sixteenth century. But the fact remains that although the Arabic historical literature of the last four centuries and a half is fairly vast and valuable, yet a good deal of it is either unexplored or poorly known. It has not received serious study because, as we said at the beginning, the whole period with which it deals has only just begun to command the interest of historians, and perhaps because it does not include works of the caliber and importance of those written by classical historians such as TTabari, Mas ${ }^{\mathrm{c}} \overline{\mathrm{u}} \mathrm{di}$ and Ibn-Khaldūn.

One of the characteristics of modern Arab historians is that their interest has gone beyond the history of their country so as to cover in varying degrees various areas and periods of world history. The claim that Arab historians have rarely concerned themselves with the writing

1 Read before the 13 th University of Kentucky Foreign Language Conference at Lexington, April 28-30, 1960.

2 Published by Maktabat al-Nahdah. In Arabic; translation of title by writer. 
of other than the history of the Arabs and of Islam is particularly true of medieval historians and of writers in the early modern period until the beginning of the nineteenth century which, for the Near East, is really a continuation of medieval times. Certain classical Arab historians

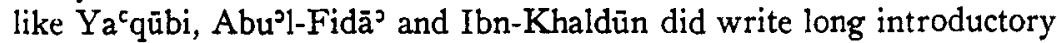
chapters on the history of the world beginning with Creation, but as soon as they reached the Islamic period, they gave all their attention to the history of Islam and the Arabs. When they touched on neighboring countries such as the Byzantine Empire, India, or Ethiopia, they did so only in so far as they were related to events occurring in the Arab world and in the lands of the Caliphate which included a major part of the world and particularly of the civilized world. The situation remained the same under the Ottoman Empire in early modern times when Arab chroniclers and biographers, living in isolation from the rest of the world and even from each other, wrote only about the events and personalities of their immediate environment and thus produced a number of regional and city histories as well as local or regional biographical dictionaries.

With the beginning of the nineteenth century the situation changes completely. Arab historians - previously unaware of world events at a time when Europe was having its Renaissance and Reformation, its scientific, industrial and political revolutions - begin to be interested in the rest of the world and particularly in Europe. Several factors were responsible for opening their eyes to conditions in Europe and stimulating their interest in European history and civilization. Among these factors we can mention Napoleon's expedition to Egypt and Syria followed by the modernizing rule of Muhammad Ali, contacts with European and American missionaries especially in the Levant countries and particularly in Lebanon, the return of students sent to study in Europe, the beginning of the cultural revival in the Arab countries, and the expansion of Western business and political interests in Arab lands.

The Arab cultural revival in the nineteenth century included, among other developments, the expansion of printing, the establishment of newspapers and the founding of schools. The Bulaq Press in Cairo, the American and the Catholic presses in Beirut were established in I822, I834 and I848 respectively. Several other printing presses followed after 1850. Newspapers and magazines sometimes had their own presses. They flourished also in the second half of the nineteenth century and it was in them that historical works were occasionally published as serials before they were put into one volume. Many of those who wrote or translated works on world or European history were journalists, littérateurs and poets. The magazine writer Jurji Yanni, for example, published a history of the Franco-German war in the Jinan magazine in Cairo, and in I9I I it appeared in a separate volume. The well known poet Khalil Mutran wrote a history of the world in two volumes which he called "The Mirror of Days on an Outline of General 
History" (Cairo, 1905). Important world events were narrated in the form of epics by contemporary observers; Faris al-Khuri, who was soon to become a leading figure in Syrian and Arab politics, composed a series of poems on the Russo-Japanese war (printed in Cairo, 1906), and Asaad Khalil Dagher wrote a long poem on the First World War (Cairo, 1919).

Military of ficers and government of ficials had their share in writing on world history. In the year 1894 the Bulaq Press published two works on the subject. The one was written by Ismail Pasha Sarhank in three volumes and contained a history of the world with special emphasis on naval history. The other was written by Mahmud Fihmi Pasha, a military engineer living in exile in Ceylon after the Arabi revolt; it was a general history in four volumes. Other authors wanted to write histories of the world, but what they published actually never went beyond ancient times. Jurji Zaydan, for example, founder of Al-Hilal, the oldest existing Arabic magazine, and otherwise known for his works on Arab history and civilization, published only one volume of his general history (Beirut, I890) and covered the ancient history of the world. A few years later he published in Cairo (1899) the history of England to the dynasty of York. Arab authors in Syria, Lebanon, Egypt and Tunisia wrote works on various European and Afro-Asian countries, particularly France, Russia, Ethiopia, Transvaal, Japan, China, and Iran. Their interest in France and Russia was a result of close contacts between these two countries and the Arabs of the Ottoman Empire. As for the other countries, it was mainly the interest in their contemporary events that prompted them to write. The Boer War, for example, led to the writing of at least three works on the history of Transvaal in the early years of the present century. The Tunisian author, Kheireddine al-Tunsi, had a practical motive when he wrote his history and description of the administrative and military conditions of each of the European kingdoms (Tunis, 1284/1867) for he puts under the title of his work the following statement as a subtitle "... That the Muslims might adopt what is most suitable for them."

The preparation of books on European and world history to serve the needs of schools became one of the main factors in historical writing. In I 835 a "School of Languages" was established in Cairo and six years later a department of translation was attached to it under the direction of one of the most prominent among the young men sent by Muhammad Ali to study in Europe; his name was Rafacat al-Tahtawi. Rafacat undertook, with the help of his students, to translate - mostly from French - books on European history at a time when historical studies were becoming a part of the curriculum in some Egyptian schools. He tried also to satisfy the curiosity of his master, Muhammad Ali, who was interested in hearing stories and experiences of great world figures. Rafacat himself had already translated a work on the character and manners of the European peoples (Bulaq, 1249/1834). One of his stu- 
dents, Abdallah Abu'1-Saud, translated a book on the history of France until the time of Louis Philippe and added to it a history of Egypt in the corresponding period (Bulaq, $1257 / 1842$ ). Other students of Rafa ${ }^{c} a t$ translated works on Charlemagne, Peter the Great, Charles XII, and on medieval history. The school of languages was closed in 1849 after Muhammad Ali's death, but Khedive Ismail re-established the department of translation in $\mathrm{I} 863$ and $\mathrm{Rafa}^{\mathrm{C}}$ at continued his activities until his death in 1873 . The best one-volume history of the world in the pre-war period was written in Beirut by Yuhanna Abqarius. Its first edition appeared in 1883 at The American Press and by I9I2 it had run through five editions.

The need for textbooks in high schools and universities became more and more urgent after 1920 as a result of the tremendous expansion in the teaching of history, the establishment of a number of state universities where teaching was in Arabic, and a more thorough study of European history in the Arab countries under European rule of influence. Books were either translated or adapted from European and American authors or were written by high school teachers and university professors. Translators and authors were generally specialists in their subjects and were connected with the institutions of learning. But when the books were not destined to the classroom and dealt with current events or famous world figures, they were written by journalists and general writers rather than by historians. Publishing houses, particularly in Egypt, and university presses in certain cases encouraged and promoted the work of translators and authors. Among the Western authors whose works on European history and biography were translated into Arabic we can mention Herbert Fisher, Duff Cooper, Ferdinand Schevill, Pierre Renouvin, Charles Diehl, André Maurois and Emil Ludwig. Almost all the Arabic works on general world history and the history of civilization in the post-war period were translations from such well known authors and historians as H. G. Wells, H. Van Loon, Will Durant, Arnold Toynbee and George Sarton. The translators were mostly university professors or college graduates and worked most of the time at the request of public or private cultural institutions such as the Cultural Section of the Arab League (W. Durant's Story of Civilization), the Cultural Section of the Ministry of Education in Egypt (John Hammerton's Encyclopedia of World History), the Committee of Authorship, Translation and Publication in Egypt (H. G. Wells' Outline of History) and Franklin Publications (Sarton's History of Science, and W. Langer's Encyclopedia of World History).

Along with the cultural awakening and the expansion of institutions of learning, the emergence of Arab nationalism in the nineteenth century and Arab interest in other national and liberation movements led to increased interest in world history and in the biography of European and other national figures. With the expansion of nationalist movements in the twentieth century and the appearance of new heroic national 
figures, it became necessary to go back to the past and to know more about the national heritage of the various peoples struggling for freedom and independence. This accounts for an additional number of books dealing with European and Asian history and biography. Among the favorite subjects for general writers and historians were the French Revolution and the life of Napoleon, Italian Unity, the Irish revolt and the lives of Mazzini, Lincoln, Gandhi, Nehru and Sun Yat-sen. The list of authors and translators of works on these subjects includes Ameen Rihani, Mustapha Ziada, Abbas Mahmud al-Aqqad, Taha alHashimi, Hassan Jalal, Mahmud al-Khafeef and Muhammad Sabri. The Italian aggression against Ethiopia brought forth a number of books in the mid-thirties on Ethiopian history and politics.

Closer relations between the Arab world and other states in the twentieth century along with the increased interaction of world events and cultures and the greater participation of the Arab states in world assemblies and conferences were other factors leading to the study of the history and culture of other nations.

It is difficult to give an exact estimate of the number of works written or translated by modern Arab historians and writers on world history in general or on the history of various non-Arab countries. But their number is not such that it cannot be approximately known. Bibliographical facilities for such an estimate are inadequate. The best available aids for the present writer were : the biblographical dictionary compiled by Yusuf Sarkis on Arabic publications since the beginning of printing until I9I9 (published in Cairo, 1928) and its supplement which carries it down to 1927; the bio-bibliographical work of Yusuf Dagher on deceased Arab writers between 1800 and 1955 (his work on contemporary Arab writers is still to appear); the histories of Arabic literature such as those of Brockelmann, Zaydan and Cheikho; the indexes of magazine book reviews prepared by a few magazines such as the index of al-Machriq (published in Beirut in 1952 for the magazine articles and book reviews that appeared in it between 1898 and 1950), and that of the Review of the Arab Academy in Damascus; a volume issued by Cairo University containing the titles of master's and doctoral dissertations submitted to it, and another volume (published in 1958) containing lists of works written or translated by its own professors; the catalogues of publications issued by various bookstores in the Arab world; and finally the book index of public and university libraries in Beirut, Damascus and Cairo.

This, of course, does not guarantee that our estimate can be exhaustive. But with these limitations in mind, we have estimated that between the middle of the nineteenth century and 1958 no less than $25^{2}$ works were written or translated on general world history or on the history of Western and Afro-Asian countries excluding the Arab world. This estimate does not include works on ancient history and on Near Eastern church history. 
Of the 252 titles mentioned above, 108 belong to the first period ending in 1919, and 144 to the second period since I920. Works on general world history and the history of civilization are relatively few, twenty-nine in all; fifteen were written in the first period and fourteen, mostly translations, in the second. Works on European history or biography number 120 , about haif the total. One-third of them were written in the first period and two-thirds in the second.. In either period, one-third of the works on European history were translations from either English or French. On the history of Asian and African countries, excluding the Arab countries, some eighty books were produced, fifty before 1920 and thirty after. Twenty per cent of all these were translations. The history of the American countries was the subject of only twenty-three works, most of which (20) appeared after 1920; they were almost all translations from English or Spanish. Five of them dealt with Latin American countries and the rest were histories of the United States and some of its national leaders, particularly Washington, Franklin, Lincoln, Jefferson and F. D. Roosevelt. The works on Latin America were all written or translated by Syrian and Lebanese emigrants in Brazil, Argentina and Chile.

Our general remarks on the work of modern Arab historians and writers on world history are: first, the number of their written or translated works is not considerable, but it far exceeds the work of medieval historians. One should also take into consideration that after the cultural renaissance in the nineteenth century, modern Arab historians were interested-but not completely absorbed-in two other major fields, namely, their own ancient history and their history in the medieval Islamic and modern periods.

Second, Arab authors have not produced original works on the history of Europe and the rest of the world based on historical research and study of documents. They have relied on secondary sources and standard works in foreign languages which they sometimes translated. The works of such university professors as Mustapha Ziada, Ahmad Naguib Hashim and Muhammad Fuad Shukri were intended either for college students or for the educated general reader. The specialists, familiar with foreign languages, could directly consult scholarly and detailed works by foreign scholars. On the other hand, most of the Arab historians of medieval or modern times concentrated their scholarly work on subjects connected with their local or national history which required study. It should be remembered also that modern historical scholarship is quite recent in the Arab world, and that specialists in non-Arab history are rare.

Third, it is to be noticed that works on the Islamic non-Arab countries and on India and the Far East are fewer than those on Europe. In the first period until I9Ig it was natural for a number of authors, mostly politicians and government of ficials-such as Sulayman Bustani, Ruhi Khalidi, Muhammad Farid and Hakki al-Azem-to write on Otto- 
man history and the Eastern question at a time when several Arab countries were a part of the Ottoman Empire. In the second period their interest in Turkey weakened in spite of its proximity to their borders and its nationalist movement in the early twenties. Only nine works (compared with thirty in the first period) were written or translated on Turkey. As for Persia, Afghanistan, Muslim India and Pakistan, only about a dozen books were produced; some of them were the work of such university professors as Yahya al-Khashshab, Mustapha Taha Badre and Ahmad Mahmud Sadati. There were even two doctoral dissertations, one written on Babur of India and the other on Ghazan of Persia. We have not come across one single book on Indonesia.

Interest in Far Eastern and American history evidently has not been strong enough to warrant the writing of adequate works on the subject. One of the main reasons is that the countries in question had neither extensive political nor commercial relations with the Arab world until recently. They were too distant, and their history has never formed a part of the curriculum in secondary schools nor has it been offered for study in universities. Even in American universities in the Middle East hardly any course has been given on American history. At one time the history of civilization in India and the Far East was introduced into the Syrian University and a book had to be written on the subject for the benefit of students, but this was only a part of a course on the general history of civilization.

With European history the situation was different and, since the nineteenth century, various factors have contributed to its study, as we have explained. The fact remains that the Arabs and the Arab countries are oriented in their trade relations and in their political and cultural contacts more towards Europe and the West than toward the Muslim or non-Muslim countries of Central, South-Eastern and Eastern Asia. This has naturally affected the subject matter of their historical works.

University of Michigan

GEORge M. HADDAD

Ann Arbor, Michigan 